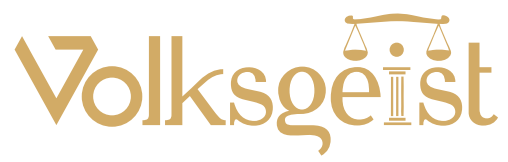

ISSN Print 2615-5648

ISSN Online 2615-174X
Kantor Editor : Lantai 2 Fakultas Syariah UIN SAIZU Purwokerto

Jl. A. Yani No. 40A Purwokerto Jawa Tengah 531226 Indonesia

Telp.

: +62 281635624 Fax. +62 281636653

: Volksgeist@uinsaizu.ac.id

: http://ejournal.uinsaizu.ac.id/index.php/Volksgeist

\title{
Regulasi Hukum Terhadap Keterlibatan Korban Tindak Pidana Penyelundupan Manusia
}

\author{
Hana Farah Dhiba, ${ }^{1}$ Sabinadevi ${ }^{2}$ \\ ${ }^{1,2}$ Politeknik Imigrasi \\ ${ }^{1}$ Email: hanafdhiba@gmail.com
}

\begin{abstract}
Abstrak
Penelitian ini bertujuan untuk menganalisis regulasi hukum terhadap korban yang terlibat terjadinya tindak pidana penyelundupan manusia dengan melihat bentuk penyertaan dan hubungan antara pelaku dan korban. Metode yang digunakan dalam penelitian adalah metode deskriptif kualitatif dengan pendekatan hukum normatif. Penelitian dilakukan dengan mengumpulkan fakta-fakta kejadian di lapangan dan menganalisisnya dengan dasar hukum perundang-undangan yang berlaku. Adapun dari hasil penelitian diperoleh kesimpulan bahwa korban tindak pidana penyelundupan manusia dapat dikenakan proses hukum akibat adanya delik penyelundupan manusia ataupun pembantuan pasif dengan berat ringannya sesuai dengan bentuk dan luasnya wujud perbuatan masing-masing orang dalam mewujudkan tindak pidana.
\end{abstract}

Kata Kunci: Regulasi hukum; penyelundupan manusia; keterlibatan korban.

\section{Abstract}

This study aims to analyze the legal regulation of victims who are involved in the occurrence of people smuggling by looking at the forms of participation and the relationship between the perpetrator and the victim. The method used in this research is a qualitative descriptive method with a normative legal approach. The research was conducted by collecting facts of events in the field and analyzing them on the basis of the applicable laws and regulations. The results of the study conclude that victims of criminal acts of human smuggling can be subjects to legal proceedings. That is due to the human smuggling offenses or passive assistance with the severity of which is in accordance with the form and extent of their actions in realizing the crime.

Keywords: Legal regulation; people smuggling; victim involvement.

\section{Sejarah Artikel}

Dikirim: 04 Oktober 2021

Direview: 09 November 2021

Diterima: 29 November 2021

Diterbitkan: 01 Desember 2021

\section{PENDAHULUAN}

Kemajuan ilmu pengetahuan dan teknologi menjadikan aspek kehidupan masyarakat yang selama ini bersifat nasional berkembang menjadi bersifat internasional. Dengan bantuan kemajuan teknologi informasi dan tranportasi, perpindahan penduduk secara mudah melintasi 
batas negara dan menyebabkan terjadinya proses transnasionalisasi berbagai aspek kehidupan. Salah satu konsekuensi terjadinya transnasionalisasi adalah terjadinya proses migrasi global atau dapat juga dikatakan bahwa globalisasi identik dengan transnasionalisasi migrasi.

Transnasional migrasi menurut Iman Santoso adalah "Migrasi manusia secara perorangan atau berkelompok dari berbagai tingkatan dan selalu disertai oleh berbagai aspek kehidupan, yang terus bergerak dari satu wilayah negara ke berbagai wilayah negara lain, baik untuk tinggal sementara atau menetap serta bersifat multidimensi dengan berbagai dampaknya sebagai suatu strategi di dalam rangka mencari peluang kehidupan yang lebih baik."

Era dunia yang makin bebas dengan sarana transformasi dan informasi yang semakin lancar, telah menunjang proses migrasi antar negara. Bergesernya loyalitas nasional dan perpindahan penduduk antar negara akibat pengaruh ekonomi global dan latar belakang yang lain telah menyebabkan Indonesia menjadi daerah rawan penyelundupan manusia. ${ }^{2}$ Salah satu faktor penyebab peningkatan kasus penyelundupan manusia di Indonesia setiap tahunnya yaitu kondisi geografis Indonesia sebagai negara kepulauan, yang memiliki banyak pulau kecil yang berada dekat dengan negara lain. Menjadikan Indonesia sebagai negara transit untuk menuju negara tujuan.

Alur penyelundupan manusia yang sekarang marak di Indonesia ini sebenarnya dapat dipetakan dalam tiga area penting, yakni

$1 \quad$ M. Iman Santoso, Prespektif Imigrasi Dalam United Nation Convention Against Transnational Organized Crime, ed. Perum Percetakan Negara RI (Jakarta, 2007).

2 Mujibussalim Evlyn Martha Julianty, Dahlan Ali, "Kebijakan Kriminal Dalam Penanggulangan Penyelundupan Manusia Di Indonesia," Jurnal Ilmu Hukum Pascasarjana Universitas Syiah Kuala 2, no. 2 (2014): 41. negara asal, negara transit, dan negara tujuan. Ketiga area ini merupakan sebuah siklus yang perlu dicermati secara mendalam apabila ingin mencari model penanganan terpadu terhadap kejahatan penyelundupan manusia. Pertama, negara asal. Negara asal para imigran adalah negara-negara Timur Tengah dan Asia Selatan. Para imigran ini banyak berasal dari Irak, Iran, Mesir, Tunisia, Suriah dan Libia. Di Timur Tengah, para imigran banyak berasal dari India, Pakistan, dan Afghanistan. Kedua, negara transit. Negara transit adalah negara yang dilewati atau disinggahi sementara oleh para imigran dari negara asal. Negara transit ini kebanyakan adalah Indonesia dan Malaysia. Para imigran ini berlayar selama sekian minggu dan kemudian singgah dan bermukim sementara di Indonesia dan Malaysia untuk kemudian bersiap-siap menempuh perjalanan ke negara Australia. Sebagai negara transit, Indonesia dijadikan sebagai persinggahan sementara oleh para imigran untuk sekedar istirahat, mengumpulkan perbekalan, dan menyiapkan tenaga untuk kembali berlayar ke Australia. Para imigran ini biasanya dibantu oleh oknum Warga Negara Indonesia (WNI) atau Warga Negara Asing (WNA) yang ada di Indonesia seperti membantu menyiapkan semua kebutuhan dan persiapan, mulai dari menentukan tempat tinggal sementara hingga menentukan lokasi pemberangkatan serta alat tranportasi yang digunakan untuk mengangkut mereka. Ketiga, negara tujuan. Negara tujuan adalah negara yang menjadi tempat terakhir atau tempat yang akan dituju oleh para imigran. Negara tujuan ini adalah kebanyakan negara Australia. Adapula yang bertujuan ke Selandia Baru, namun sebagian besar adalah negara Australia. $^{3}$

Pola migrasi ilegal yang terjadi di Indonesia khususnya di pulau-pulau perbatasan Indonesia

3 Agus Subagyo and Dadang Sobar Wirasuta, "Penyelundupan Manusia Dan Ancaman Keamanan Maritim Indonesia Desember 2013," Jurnal Pertahanan 3, no. 3 (2013): 155. 
pada akhirnya berimplikasi pada munculnya masalah keamanan berupa aksi-aksi kejahatan yang melintasi batas negara (transnational crime), juga kejahatan transnasional yang terorganisir (transnational organized crime). Transnational organized crime adalah suatu kelompok terstruktur yang terdiri dari tiga orang atau lebih, terbentuk dalam satu periode waktu dan bertindak secara terpadu dengan tujuan untuk melakukan satu tindak pidana serius atau pelanggaran atau lebih yang ditetapkan menurut Konvensi, untuk mendapatkan, secara langsung atau tidak langsung, keuntungan keuangan atau materi lainnya. ${ }^{4}$

Penyelundupan manusia dan imigran ilegal mempunyai keterkaitan satu sama lain. Imigran ilegal berhasil masuk ke negara transit maupun negara tujuan tidak selalu membutuhkan kerjasama dengan para agen penyelundup, mereka juga dapat menyelundupkan dirinya sendiri ke negara tujuan tanpa membutuhkan agen penyelundup. ${ }^{5}$

Penyelundupan ini ditujukan untuk memasok pasar perdagangan seks internasional dan buruh. Penyelundupan tersebut dilakukan melalui jejaring kejahatan internasional yang terorganisasi baik melalui jalur negara perantara maupun langsung. Semakin meningkatnya secara signifikan aktivitas kelompok kejahatan terorganisir dalam terjadinya penyelundupan migran, dapat membahayakan Negara-negara dan kehidupan serta keselamatan para migran itu sendiri. Hasil temuan dari buku yang disusun oleh International Organization for Migration (IOM) menunjukkan bahwa adanya transaksi uang yang tidak sedikit dalam penyelundupan manusia. Biaya yang harus dikeluarkan oleh setiap korban kepada pelaku penyelundupan

$4 \quad$ UNTOC, "United Nations, Convention Against Transnational Organized Crime" (n.d.).

5 Kadarudin, "People Smuggling Dalam Perspektif Hukum Internasional Dan Penegakan Hukumnya Di Indonesia," Jurnal Perpustakaan XII, no. 2 (2013): 69-70. berkisar antara US\$ 3.000 - US 15.000 per korban. Tentu ini jumlah yang tidak sedikit. Berbagai modus operandi yang dilakukan dalam penyelundupan manusia dengan melibatkan berbagai pihak atau pelaku. Setidaknya ada dua peran dalam penyelundupan manusia, yakni sebagai otak penyelundupan yang bersifat pasif dan berada di negara asal, dan ada yang berperan sebagai agen penyelundupan yang bersifat aktif berasa di negara transit atau negara tujuan. Dengan begitu, dapat dikatakan bahwa penyelundupan manusia adalah kejahatan yang terstruktur. ${ }^{6}$

Melihat dampak dan perkembangan jenis kejahatan ini yang semakin luas maka dunia internasional sepakat membuat instrumen hukum internasional untuk bersama-sama memberantas tindak pidana transnasional yang terorganisir melalui United Nations Convention Against Transnational Organized Crime Tahun 2000 (Konvensi Perserikatan Bangsa-Bangsa Menentang Tindak Pidana Transnasional yang Terorganisir, yang selanjutnya akan disebut UNTOC). Indonesia sendiri sudah meratifikasi konvensi tersebut melalui Undang-Undang No. 5 tahun 2009. Seiring perkembangannya pada tahun 2004 dibentuk protokol tambahan dari UNTOC tahun 2000 tersebut yaitu Protokol Against The Smuggling of Migrant by Land, Sea, and Air, Supplementing the United Nations Convention Against Transnational Organized Crime (Protokol Menentang Penyelundupan Migran Melalui Darat, Laut, dan Udara, Melengkapi Konvensi Perserikatan Bangsa Bangsa Menentang Tindak Pidana Transnasional yang Terorganisir). Protokol tambahan ini sudah diratifikasi oleh Indonesia melalui Undang-undang No. 15 Tahun 2009.

Konsekuensi sebuah negara menjadi salah satu Negara Peserta (mengikatkan diri) atas suatu perjanjian internasional adalah

6 International Organization for Migration, Penyelidikan Dan Penyidikan Dalam Tindak Pidana Penyelundupan Manusia, 2012. 
munculnya hak dan kewajiban negara pihak yang mengadakannya. Daya ikat atas perjanjian tersebut didasarkan atas prinsip pacta sunt servanda. Konvensi Wina tahun 1969 tentang Hukum Perjanjian menyatakan bahwa tiap-tiap perjanjian berlaku mengikat bagi negaranegara pihak dan para pihak tersebut harus melaksanakan kewajibannya dengan itikad baik (good faith) demi tercapainya maksud dan tujuan dari perjanjian tersebut. Setiap Negara Peserta perjanjian harus menghormati hak-hak dan kewajiban-kewajiban dari masing-masing pihak maupun pihak ketiga yang mungkin diberikan hak dan atau dibebani kewajiban. ${ }^{7}$ Pasal 4 ayat (1) Undang-undang No. 24 tahun 2000 tentang Perjanjian Internasional yang menyatakan:

"Pemerintah Republik Indonesia membuat perjanjian internasional dengan satu Negara atau lebih, organisasi internasional, atau subyek hukum internasional lain berdasarkan kesepakatan; dan para pihak berkewajiban untuk melaksanakan perjanjian tersebut dengan itikad baik".

Salah satu kewajiban dari negara peserta UNTOC dan protokolnya adalah perlindungan korban. Dalam perlindungan korban, negara peserta wajib untuk melestarikan dan melindungi hak orang yang menjadi objek kegiatan penyelundupan manusia khususnya hak untuk hidup, hak untuk tidak disiksa, atau perlakuan atau penghukuman lain yang kejam, tidak manusiawi, dan merendahkan martabat manusia. $^{8}$

Ditinjau dari persfektif tanggung jawab korban dikenal istilah Provocative Victims yaitu korban yang disebabkan peranannya untuk memicu terjadinya kejahatan. Oleh karena

I Wayan Pathriana, "Hukum Perjanjian Internasional," in 2 (Bandung, 2005), 261-63.

8 Air United Nations, Protokol Against The Smuggling of Migrant by Land, Sea, Supplementing the United Nations Convention Against Transnational Organized Crime, n.d. itu, dari aspek tanggung jawab terletak pada diri korban dan pelaku secara bersama-sama. Menurut Hukum Nasional yang tertuang pada Kitab Undang-Undang Hukum Pidana (KUHP) dikenal delik penyertaan (deelneming).

Sudah ada beberapa penelitian sebelumnya yang mengkaji tentang penyelundupan manusia, diantaranya penelitian Junef ${ }^{9}$, dalam penelitian tersebut dikaji mengenai bagaimana praktik penyelundupan manusia yang marak terjadi di Indonesia, faktor-faktor yang menyebabkan maraknya praktik penyelundupan manusia dan upaya pemerintah dalam menanggulangi kejahatan tersebut.

Selanjutnya penelitian lain yang membahas tentang penyelundupan manusia oleh Yasmirah $^{10}$, penelitian ini mengkaji tentang analisis peraturan hukum terhadap imigran illegal yang menjadi pelaku penyelundupan manusia di Indonesia serta penanganannya oleh pemerintah.

Penelitian dengan judul "Penegakan Hukum Tindak Pidana Penyelundupan Manusia (People Smuggling) dalam hukum positif Indonesia" dilakukan oleh Eka Annisa Salam menitikberatkan pada penegakan hukum terhadap tindak pidana penyelundupan manusia berdasarkan Undang-Undang Keimigrasian yang belum maksimal. Selain itu, turut dibahas kebijakan formulasi di masa mendatang guna menangani kasus penyelundupan manusia ${ }^{11}$.

Berdasarkan penelitian yang telah dilakukan tersebut, maka penelitian yang membahas regulasi hukum terhadap korban tindak pidana perdagangan manusia layak

$9 \quad$ Muhar Junef, "Kajian Praktik Penyelundupan Manusia Di Indonesia (Study of People Smuggling Practices in Indonesia)," Jurnal Pendidikan Hukum De Jure 20, no. 1 (2020): 85-102.

10 Yasmirah Mandasari Saragih et al., "Penegakan Hukum Terhadap Pelaku Penyelundupan Manusia Ke Indonesia" 4, no. 1 (2021): 161-74.

11 Eka Annisa Salam, "Penegakan Hukum Tindak Pidana Penyelundupan Manusia Dalam Hukum Positif Indonesia” 3, no. April 2020 (2020): 9-20. 
untuk diteliti. Oleh sebab itu, penelitian ini melengkapi penelitian yang membahas tentang penyelundupan manusia di Indonesia yang telah ada sebelumnya. Perbedaan penelitian ini dibandingkan dengan ketiga penelitian di atas adalah dalam penelitian ini menitikberatkan pada analisis regulasi dan upaya hukum bagi korban yang turut serta dalam tindak pidana penyelundupan manusia.

Penelitian ini adalah penelitian hukum normatifyang bersifat kualitatif. Ronny Hanitijo Soemitro mengemukakan bahwa penelitian hukum normatif yang juga bisa disebut dengan penelitian hukum doktrinal yang menggunakan sumber data sekunder berupa peraturan perundang-undangan, keputusan-keputuasan pengadilan, teori hukum, dan pendapat para sarjana terkemuka dalam proses pengambilan datanya. ${ }^{12}$

Penelitian ini merupakan studi kepustakaan sebagai upaya dalam menemukan kolerasi atau relevansi teori terkait penelitian ini. Sementara, teknik pengumpulan data yang digunakan adalah dokumen-dokumen atau bahan-bahan tertulis yang ada relevan terhadap penelitian. Adapun bahan datanya adalah bahan hukum primer dan bahan hukum sekunder. Analisis data yang digunakan adalah analisis hukum normatif karena yang menjadi objek dalam penelitian ini adalah atuaran perundangundangan yang mempunyai kekuatan hukum tetap dan mengikat. Analisis terhadap aturan perundang-undangan hanya dilakukan terhadap pasal-pasal yang isinya merupakan kaedah. Setelah dilakukan analisa, maka kontruksi dilaksanakan dengan memasukkan pasal-pasal tertentu ke dalam kategori-kategori atas dasar pengertian-pengertian dasar dari sistem hukum tersebut. ${ }^{13}$

\footnotetext{
12 Subana, Dasar-Dasar Penelitian Ilmiah (Bandung: CV Pustka Setia, 2010).

13 Soerjono Soekanto, Faktor-Faktor Yang Mempengaruhi Penegakan Hukum (Jakarta: PT. Raja Grafindo Persada, 2008).
}

\section{PEMBAHASAN}

\section{Tinjauan Umum Tentang Penyelundupan Manusia di Indonesia}

Menurut Deputi Bidang Keamanan Nasional Menkopolhukam Bambang Suparno, salah satu masalah yang dihadapi dalam menangani masalah imigran ilegal yaitu lemahnya regulasi. Khususnya yang mengatur tentang penanganan imigran ilegal yang masuk ke Indonesia. Mengingat Australia sebagai negara tujuan, maka Indonesia berpotensi besar menjadi tempat singgah para imigran ilegal. Oleh karenanya Pemerintah Australia kerap mendesak Indonesia untuk aktif dan serius menangani imigran ilegal. Sehingga dapat dihadang agar tidak masuk ke wilayah Australia.

Dari tahun ke tahun imigran ilegal dan penyelundupan orang ke Indonesia dan transit melalui Indonesia semakin meningkat. Hal ini terbukti dari fakta yang diperoleh menunjukan bahwa dari waktu ke waktu, cara-cara ilegal justru lebih menjadi pilihan dalam proses migrasi. Laporan dari Bureau of Public Affairs, US Departement of State pada bulan Juni 2003 memaparkan bahwa tiap tahun sekitar 800.000 s/d 900.000 orang telah diselundupkan dengan mengabaikan batas-batas internasional. ${ }^{14}$

Keberadaan imigran ilegal dan interaksinya dengan warga Indonesia berdampak sosial psikologis terhadap kondisi imigran ilegal maupun warga Negara Indonesia. Dampak sosial psikologis dari interaksi sosial yang dialami oleh imigran ilegal maupun warga Negara Indonesia tampaknya cenderung mengakibatkan masalah yang lebih serius jika tidak ditangani secara komprehensif. Berangkat dari kenyataan obyektif bahwa pengalaman konflik di masa lalu dan atau pengalaman mengalami diskrimanasi, serta beberapa hidup dalam kemiskinan di negara asal maupun negara

14 M. Imam Santoso, Hukum Pidana Internasional (Bandung: Pustaka Reka Cipta, 2013). 
kedua sebelum masuk Indonesia sebagai push factor sebagian besar imigran ilegal berimigrasi. Maka dapat dipastikan bahwa mereka masuk ke Indonesia dengan kondisi psikososial yang rentan. Stress paska pengalaman traumatik, prasangka terhadap outgroup, kecenderungan perilaku agresif dialami oleh mereka ketika masuk Indonesia. Kodisi psikososial yang negatif ini tampaknya semakin memburuk karena pengalaman negatif yang diperoleh dalam perjalanan menuju negara tujuan akhir maupun ditangkap serta ditahan di Indonesia. Konsekuensi logis dari kondisi psikososial yang negatif tentunya mempengaruhi imigran illegal dan interaksinya terhadap warga Negara Indonesia dan meningkatkan kerentanan terjadinya masalah psikososial yang serius. Kondisi psikososial yang serius tentunya memerlukan penanganan yang lebih profesional. Kenyataanya akses untuk mendapatkan penanganan yang lebih profesional masih sangat terbatas. Dampak ke depan diduga akan muncul antara lain meningkatnya prilaku beresiko imigran ilegal sebagai bentuk upaya/ aktifitas untuk mengurangi stres (stress-relief activities), misalnya peningkatan konsumsi alkohol dan prostitusi.

Hal ini tentunya menimbulkan masalah sosial yang menjadi beban Indoensia. Potensi kekerasan yang dilakuakan oleh imigran ilegal sebagai ekspresi frustasi pun sangat besar kemungkinannya akan terjadi. Motivasi yang sangat besar untuk sukses, tiba di negara tujuan utama untuk dapat memperbaiki keadaaan ekonomi keluarga dan hidup aman dan damai seperti yang dicita-citakan, kemungkinan besar mendorong imigran ilegal untuk menggunakan berbagai upaya dan kesempatan (tujuan menghalalkan segala cara) untuk mendapatkannya termasuk berbuat kriminal, melanggar hukum atau aturan yang ada di Indonesia. Hal ini sangat mungkin terjadi terutama apabila imigran ilegal menyadari bahwa aspek penegakan hukum di Indonesia relatif rendah.

\section{Tinjauan Umum Tentang United Nations Convention Against Transnational Orga- nized Crime}

Tujuan Konvensi ini adalah untuk memajukan kerja sama untuk mencegah dan memberantas tindak pidana transnasional terorganisasi secara lebih efektif. Tujuan Konvensi ini, maka disamakan persepsi pada setiap negara peserta tentang pemakaian istilah, yakni;

1. "Kelompok pelaku tindak pidana terorganisasi" berarti suatu kelompok terstruktur yang terdiri dari tiga orang atau lebih, terbentuk dalam satu periode waktu dan bertindak secara terpadu dengan tujuan untuk melakukan satu tindak pidana serius atau pelanggaran atau lebih yang ditetapkan menurut Konvensi ini, untuk mendapatkan, secara langsung atau tidak langsung, keuntungan keuangan atau materi lainnya;

2. "Tindak pidana serius" berarti tindakan yang merupakan suatu tindak pidana yang dapat dihukum dengan maksimum penghilangan kemerdekaan paling kurang empat tahun atau sanksi yang lebih berat;

3. "Kelompok terstruktur" berarti suatu kelompok yang tidak secara acak dibentuk untuk melakukan tindak pidana dengan segera dan tidak perlu memiliki peran yang ditetapkan secara formal bagi para anggotanya, kesinambungan dari keanggotaannya maupun suatu struktur yang jelas;

4. "Kekayaan" berarti aset berbentuk apapun, baik berbentuk atau tidak berbentuk, bergerak atau tidak bergerak, berwujud atau tidak berwujud, dan dokumen atau instrumen hukum yang membuktikan hak 
atas, atau kepentingan terhadap, asset tersebut;

5. "Hasil tindak pidana" berarti setiap kekayaan berasal dari atau diperoleh, secara langsung atau tidak langsung, melalui pelaksanaan suatu tindak pidana;

6. "Pembekuan" atau "penyitaan" berarti pelarangan sementara pemindahan, konversi, pelepasan atau perpindahan kekayaan, atau menerima penjagaan atau pengawasan kekayaan secara sementara berdasarkan suatu perintah yang dikeluarkan oleh pengadilan atau badan berwenang lainnya;

7. "Perampasan" yang meliputi perampasan bilamana dapat diberlakukan, berarti pencabutan permanen atas kekayaan dengan perintah pengadilan atau badan berwenang lainnya;

8. "Tindak pidana asal" berarti setiap tindak pidana yang mana hasil-hasil yang diperolehnya dapat menjadi subjek dari suatu tindak pidana sebagaimana dimaksud dalam Pasal 6 Konvensi ini;

9. "Organisasi regional integrasi ekonomi" berarti suatu organisasi yang dibentuk oleh Negara-negara berdaulat dalam suatu wilayah, yang Negaranegara Pihaknya telah menyerahkan kompetensinya dalam hal yang diatur dalam Konvensi ini dan yang telah diberikan kuasa, menurut prosedur internalnya, untuk menandatangai, mengesahkan, menerima, menyetujui atau mengikat; referensi "Negara-Negara Pihak" dalam Konvensi ini berlaku pada organisasi-organisasi tersebut dalam batasbatas kewenangan mereka.

Prinsip Konvensi menyatakan bahwa negara pihak, dalam menjalankan kewajibannya, wajib mematuhi prinsip kedaulatan, keutuhan wilayah, dan tidak mencampuri urusan dalam negeri negara lain. Sedangkan ruang lingkup Konvensi menyatakan bahwa Konvensi ini mengatur mengenai upaya pencegahan, penyidikan dan penuntutan atas tindak pidana pencucian hasil kejahatan, korupsi, dan tindak pidana terhadap proses peradilan, serta tindak pidana yang serius, yang bersifat transnasional dan melibatkan suatu kelompok pelaku tindak pidana yang terorganisasi.

Konvensi menyatakan bahwa suatu tindak pidana dikategorikan sebagai tindak pidana transnasional yang terorganisasi jika tindak pidana tersebut dilakukan:

1. Lebih dari satu wilayah negara;

2. Suatunegara,tetapipersiapan,perencanaan, pengarahan atau pengendalian atas kejahatan tersebut dilakukan di wilayah negara lain;

3. Suatu wilayah negara, tetapi melibatkan suatu kelompok pelaku tindak pidana yang terorganisasi yang melakukan tindak pidana di lebih dari satu wilayah negara; atau

4. Suatu wilayah negara, tetapi akibat yang ditimbulkan atas tindak pidana tersebut dirasakan di negara lain

Konvensi menyatakan bahwa Negara Pihak wajib melakukan segala upaya termasuk membentuk peraturan perundang-undangan nasional yang mengkriminalkan perbuatan yang ditetapkan dalam Pasal 5, Pasal 6, Pasal 8, dan Pasal 23 Konvensi serta membentuk kerangka kerja sama hukum antarnegara, seperti ekstradisi, bantuan hukum timbal balik dalam masalah pidana, kerja sama antaraparat penegak hukum dan kerja sama bantuan teknis serta pelatihan.

\section{Tinjauan Umum Tentang Korban Kejahatan}

\section{Pengertian Korban}

Secara luas, pengertian korban diartikan bukan hanya sekedar korban yang menderita langsung, akan tetapi korban tidak langsung pun juga mengalami penderitaan yang dapat diklarifikasikan sebagai korban. Yang 
dimaksud korban tidak langsung di sini seperti, istri kehilangan suami, anak yang kehilangan bapak, orang tua yang kehilangan anaknya, dan lainnya. ${ }^{15}$

Selanjutnya secara yuridis, pengertian korban termaktub dalam Undang-Undang Nomor 13 Tahun 2006 Tentang Perlindungan Saksi dan Korban, yang dinyatakan korban adalah "seseorang yang mengalami penderitaan fisik, mental, dan/atau kerugian ekonomi yang diakibatkan oleh suatu tindak pidana. Melihat rumusan tersebut, yang disebut korban adalah: a. Setiap orang; b. Mengalami penderitaan fisik, mental, dan/atau; c. Kerugian ekonomi; d. Akibat tindak pidana.

Dalam kajian viktimologi terdapat presfektif dimana korban bukan saja bertanggung jawab dalam kejahatan itu sendiri tetapi juga memiliki keterlibatan dalam terjadinya kejahatan. Menurut Stephen Schafer, dari persfektif tanggung jawab korban itu sendiri mengenal tujuh bentuk, yakni:

a. Unrelated victims adalah mereka yang tidak ada hubungan dengan si pelaku dan menjadi korban karena memang potensial. Untuk itu, dari aspek tanggung jawab sepenuhnya berada dipihak korban;

b. Provocative victims merupakan korban yang disebabkan peranan korban untuk memicu terjadinya kejahatan. Karena itu, dari aspek tanggung jawab terletak pada diri korban dan pelaku secara bersamasama;

c. Participating victims yakni perbuatan korban tidak disadari dapat mendorong pelaku melakukan kejahatan. Misalnya, mengambil uang di Bank dalam jumlah besar yang tanpa pengawalan, kemudian dibungkus dengan tas plastik sehingga mendorong orang untuk merampasnya. Aspek ini pertanggungjawaban sepenuhnya ada pada pelaku;

15 Muhadar, Viktimisasi Kejahatan Pertanahan (Yogyakarta, 2006). d. Biologically weak victim adalah kejahatan disebabkan adanya keadaan fisik korban seperti wanita, anak-anak, dan manusia lanjut usia (manula) merupakan potensial korban kejahatan. Ditinjau dari aspek pertanggungjawabannya terletak pada masyarakat atau pemerintah setempat karena tidak dapat memberi perlindungan kepada korban yang tidak berdaya;

e. Social weak victims adalah korban yang tidak diperhatikan oleh masyarakat bersangkutan seperti para gelandangan dengan kedudukan sosial yang lemah. Untuk pertanggungjawabannya secara penuh terletak pada penjahat atau masyarakat;

f. Selfvictimizing victims adalah korban kejahatan yang dilakukan sendiri (korban semu) atau kejahatan tanpa korban. Pertanggungjawabannya sepenuhnya terletak pada korban karena sekaligus sebagai pelaku kejahatan;

g. Political victims adalah korban karena lawan politiknya. Secara sosiologis, korban ini tidak dapat dipertanggungjawabkan kecuali adanya perubahan konstelasi politik. ${ }^{16}$

\section{Klausa Turut Serta Korban Dalam Terjadinya Tindak Pidana Penyelundupan Manusia}

Pengertian turut serta (ikut serta, bersamasama) melakukan perbuatan pidana (delict) dapat dilakukan oleh beberapa orang bersama-sama. Turut serta (deelneming) dari beberapa orang dalam perbuatan pidana dapat merupakan kerjasama, yang masing-masing dapat berbeda-beda sifat dan bentuknya. ${ }^{17}$

Menurut R. Soesilo dijelaskannya bahwa,

16 Lilik Mulyadi, Kapita Selekta Hukum Pidana Kriminologi Dan Viktimologi (Denpasar, Bali: Djambatan, 2017).

17 Umar Said Sugiarto, Pengantar Hukum Indonesia (Jakarta: Sinar Grafika, 2015). 
turut serta dalam arti kata 'bersama-sama melakukan' sedikitnya harus ada dua orang yang melakukan (pleger) dan orang yang turut melakukannya (medepleger) peristiwa pidana itu. Contoh A berniat mencuri di rumah B dan sengaja C untuk bersama-sama melakukan. Kedua-keduanya masuk rumah dan mengambil barang-barang, atau C yang menggali lubang, sedangkan A yang masuk dan mengambil barang-barangnya. Disini $\mathrm{C}$ dihukum sebagai 'medepleger', karena melakukan perbuatan pelaksanaan pencurian itu. Andaikata $\mathrm{C}$ hanya berdiri di luar untuk menjaga dan memberi isyarat kalau ada orang datang, maka C dihukum sebagai "medeplichtige', Pasal 56 sebab perbuatannya hanya bersifat menolong saja. ${ }^{18}$

Pandangan Pompe tentang medepleger adalah turut mengerjakan terjadinya sesuatu tindak pidana dengan adanya 3 (tiga) kemungkinan, yaitu:

a. Mereka masing-masing memenuhi semua unsur dalam rumusan delik. Misal dua orang dengan bekerjasama melakukan pencurian di sebuah gudang beras;

b. Salah seorang memenuhi semua unsur delik, sedang yang lain tidak. Misal dua orang pencopet (A dan B) saling bekerjasama, A yang menabrak orang yang menjadi sasaran, sedang B yang mengambil dompet orang itu;

c. Tidak seorangpun memenuhi unsur-unsur delik seluruhnya, tetapi mereka bersamasama mewujudkan delik itu. Misal dalam pencurian dengan merusak (Pasal 363 ayat 1 ke 5 KUHP) salah seorang melakukan pengangsiran, sedang kawannya masuk rumah dan mengambil barang-barang yang kemudian diterimakan kepada kawannya yang mengangsir tadi. ${ }^{19}$

18 R. Soesilo, Kitab Undang-Undang Hukum Pidana (KUHP) Serta Penjelasannya Pasal Demi Pasal (Bogor, 1985).

19 Muhammad Ainul Syamsu, Pergeseran
Menurut Satochid Kartanegara dalam melihat pada hubungan tiap peserta dengan pertanggungjawaban pidananya, maka menurut sifatnya deelneming itu dapat dibedakan dalam dua bentuk yaitu;

a. Bentuk-bentuk deelneming yang berdiri sendiri, dalam bentuk ini pertanggungjawaban dari tiap-tiap peserta dihargai sendiri-sendiri;

b. Bentuk deelneming yang tidak berdiri sendiri, disebut juga "accessori deelneming", pertanggungjawaban dari peserta yang satu digantungkan pada perbuatan peserta yang lain, yakni dilakukannya sesuatu perbuatan yang dapat dihukum kepada satu peserta, maka peserta yang satu yang lain pun juga dapat dihukum. ${ }^{20}$

Pemberian kesempatan, sarana atau keterangan adalah cara untuk menggerakkan seseorang. Jelas kiranya bahwa jika ada pembantu tentu ada yang dibantu, yaitu yang disebut sebagai pelaku utama atau petindak. Hubungan antara pembantu dengan petindak atau pelaku utama adalah pembantuan. Pembantuan ditentukan bersamaan dengan terjadinya kejahatan. Pembantuan dibagi menjadi dua jenis yakni; Pembantuan aktif (active medeplichtigheid) dan Pembantuan pasif (passive medeplichtigheid). Dalam doktrin hukum pidana, dikenal ada dua sistem pembebanan pertanggungjawaban pidana pada penyertaan, yakni;

a. Setiap orang yang terlibat bersama-sama kedalam suatu tindak pidana dipandang dan dipertanggung jawabkan secara sama dengan orang yang sendirian melakukan tindak pidana tanpa dibeda-bedakan baik

Turutserta Melakukan Dalam Ajaran Penyertaan, Telaah Kritis Berdasarkan Teori Pemisahan Tindak Piana Dan Pertanggungjawaban Pidana (Prenadamedia Group, 2014).

20 Satochid Kartanegara, "Kumpulan Kuliah Hukum Pidana," in 1 (Balai Lektur Mahasiswa, n.d.), 419. 
atas perbuatan yang dilakukannya maupun apa yang ada dalam sikap batinnya;

b. Masing-masing orang yang bersamasama terlibat dalam suatu tindak pidana dipandang dan dipertanggungjawabkan berbeda-beda, yang berat ringannya sesuai dengan bentuk dan luasnya wujud perbuatan masing-masing orang dalam mewujudkan tindak pidana.

Dalam terjadinya tindak pidana penyelundupan manusia, terkadang para korban masuk dalam kriteria orang yang melakukan turut serta (medepleger). Para korban tidak secara langsung turut serta dalam terjadinya tindak pidana penyelundupan manusia secara keseluruhan, namun melakukan perbuatan yang dapat membantu terwujudnya tindak pidana penyelundupan manusia. Diantara penyertaan yang korban lakukan adalah: masuk dan/atau berada di Indonesia menggunakan dokumen perjalanan yang tidak sah. ${ }^{21}$

Korban yang akan diselundupkan ke negara tujuan biasanya berasal dari negara rawan atau negara yang disinyalir banyak warga negaranya yang menjadi imigran ilegal. Negara tujuan para korban biasanya akan melakukan pemeriksaan yang lebih ketat pada mereka sebagai bentuk pencegahan terhadap imigran ilegal yang coba masuk ke dalam wilayah negara mereka. Untuk menyembunyikan identitas mereka, para korban menggunakan dokumen perjalanan palsu/ dipalsukan atau menggunakan paspor sah tapi bukan miliknya. Dalam mendapatkan dokumen yang tidak sah ini, korban akan dibantu oleh pelaku penyelundupan manusia.

Seperti percobaan penyelundupan manusia yang terjadi di Tempat Pemeriksaan Imigrasi Soekarno-Hatta. Petugas Imigrasi Kelas I Khusus Soekarno-Hatta mengamankan 5

21 SR Sianturi, Asas-Asas Hukum Pidana Di Indonesia Dan Penerapannya (Jakarta: Storia Grafika, 2002).
WNA di Terminal 2 Bandara Internasional Soekarno-Hatta (Soetta). Kelima WNA tersebut diamankan lantaran diduga merupakan sindikat penyelundupan manusia. Dari kelima WNA tersebut, 2 diantaranya merupakan WN Malaysia yang masing-masing berinisial SRP dan RU. Sementara 3 lainnya merupakan WN Srilanka dengan inisial MPS, TM dan MS. SRP dan WN datang ke Indonesia menggunakan pesawat Asiana Airlines QZ726. ${ }^{22}$

Pada kasus ini terlihat bahwa MPS, TM dan MS sebagai korban ikut turut serta dalam tindak penyelundupan manusia. Mereka secara sadar dan sengaja bekerja sama dengan para penyelundup manusia dalam terjadinya tindak pidana. Mereka masuk ke wilayah Malaysia dengan paspor asli milik mereka dan setibanya di Malaysia mereka dibantu oleh para penyelundup manusia memperoleh paspor Malaysia asli yang bukan miliknya atau dikenal dengan istilah impostor. Lalu dengan paspor Malaysia itu, para korban mencoba masuk ke negara transit selanjutnya yakni Indonesia. Berarti para korban juga turut serta secara fisik dalam terjadinya penyelundupan manusia. Sehingga syarat turut serta dalam tindak pidana terpenuhi oleh para korban tersebut.

Tindakan turut serta para korban ini memang tidak memenuhi unsur-unsur delik penyelundupan manusia, tetapi para korban bersama dengan pelaku mewujudkan delik penyelundupan manusia. Sehingga dalam pertanggungjawabannya, para korban harus dihargai sendiri atas tindakan yang mereka lakukan. Mereka telah memenuhi unsur delik tindak pidana sesuai dengan UU No.6 Tahun 2011 Tentang Keimigrasian pasal 119 ayat (1) yang berbunyi: "Setiap Orang Asing yang masuk dan/atau berada di wilayah Indonesia yang tidak memiliki Dokumen Perjalanan dan

22 Iman Achdiat, "Sindikat Penyelundupan Manusia Dibongkar Imigrasi Soetta," Air Magazine (Jakarta, 2017). 
Visa yang sah dan masih berlaku sebagaimana dimaksud dalam Pasal 8 dipidana dengan pidana penjara paling lama 5 tahun dan pidana denda paling banyak Rp. 500.000.000,00 (lima ratus juta rupiah)".

Selain itu, dalam perjalanannya ke negara tujuan, para korban kerap menyalahgunakan izin tinggal. Misal saat masuk ke negara Indonesia, mereka memberikan keterangan palsu kepada petugas agar dapat masuk ke wilayah negara Indonesia. Biasanya mereka beralibi akan melakukan wisata atau kunjungan keluarga di Indonesia. Pada kenyataannya mereka berada di Indonesia untuk menunggu keberangkatan mereka menuju negara tujuan. Bahkan tidak jarang mereka berada di Indonesia sampai masa berlaku izin tinggalnya habis.

Modus operandi ini dilakukan oleh para korban dengan sebelumnya telah berkoordinasi terlebih dahulu dengan pelaku penyelundupan manusia yang biasanya sudah berada atau memang warga negara di negara transit. Di negara transit oleh pelaku, para korban telah disediakan tempat penampungan sementara sebelum diberangkatkan ke negara tujuan.

Seperti percobaan penyelundupan manusia yang terjadi di Riau. Badan Reserse Kriminal (Bareskrim) Polri mengungkap sindikat penyelundupan orang ke Malaysia. Penangkapan di Riau berawal dari patroli yang digelar petugas. Saat itu polisi curiga pada seorang warga negara Bangladesh yang gerakgeriknya mencurigakan. Berdasarkan hasil pemeriksaan awal, petugas menduga ia adalah pelaku penyelundupan orang. Polisi kemudian memeriksa rumah warga tersebut. Petugas mendapati 74 orang warga negara asing. Dari pengembangan yang dilakukan, petugas kemudian menangkap tiga orang lainnya yang merupakan anggota sindikat ini. Salah satunya Tengku Said Saleh alias Haji Saleh yang diduga menjadi penyedia kapal dan membawa imigran masuk ke Malaysia maupun ke Australia. Menurut Herry, sindikat penyelundupan orang di Dumai ini telah menyelundupan sekitar 2.710 WNA selama delapan bulan terakhir. "Dia bawa masuk 600 orang dalam satu bulan. Selama delapan bulan terakhir hampir 2.000 orang. Empat tersangka dari sindikat penyelundupan orang di Dumai ini akan dijerat Pasal 120 dan Pasal 124 Undang-undang Nomor 6 Tahun 2011 tentang Keimigrasian. ${ }^{23}$

Pada kasus percobaan penyelundupan ini, para korban menyalahgunakan izin tinggal dengan kegiatannya di rumah warga untuk menunggu keberangkatan ke negara tujuan. Biasanya dalam menunggu keberangkatannya, saat masuk ke wilayah negara Indonesia para korban menggunakan fasilitas Bebas Visa Kunjungan. Dalam hal meneruskan perjalanan ke negara lain, diperuntukkan bagi WNA yang akan melakukan transit ke negara lain secara legal dan sah. Jadi kegiatan yang dilakukan para korban dengan menunggu pemberangkatan penyelundupan ke negara tujuannya adalah bentuk penyalahgunaan izin tinggal.

Selain itu, modus yang paling sering dilakukan oleh penyelundup manusia adalah menyelundupkan para korban tidak melalui Tempat Pemeriksaan Imigrasi. Hal ini tentu untuk menghindari pemeriksaan oleh Petugas dan lebih memudahkan untuk menyelundupkan lebih banyak orang. Penyelundupan menggunakan alat pengangkut yang legal akan lebih menyulitkan bagi para penyelundup dan korban untuk masuk ke wilayah negara tujuan. Karena dengan menggunakan alat angkut legal, keamanan akan lebih ketat dan tentunya harus melewati pemeriksaan keimigrasian. Sehingga para penyelundup lebih sering menggunakan alat angkut illegal dan melalui jalur illegal yang minim pengamanan dari petugas.

23 Martahan Sohuturon, "Bareskrim Ungkap Sindikat Penyelundupan Orang Ke Australia," cnn indonesia, 2019. 
Para korban secara sadar dan sengaja untuk naik ke alat angkut illegal ini. Mereka tahu kalau akan diselundupkan melalui jalur illegal yang tanpa melalui pemeriksaan keimigrasian. Tindakan para korban ini memang dikehendaki oleh si para korban untuk terjadi agar penyelundupan manusia atas dirinya dapat terlaksana.

Seperti percobaan penyelundupan manusia yang terjadi di Entikong. Aksi penyelundupan manusia dengan modus baru berhasil diungkap kepolisian dan petugas Imigrasi di Pos Lintas Batas Negara (PLBN) Entikong, Kabupaten Sanggau, Kalimantan Barat (Kalbar). Sebanyak dua dari tiga warga negara Indonesia (WNI) asal Nusa Tenggara Barat (NTB) disembunyikan pelaku di bagasi belakang mobil yang mereka tumpangi. Keduanya ditumpuk bersamaan dengan tas bawaan. Dari kejadian itu, petugas Imigrasi bersama anggota Polsek Entikong melakukan pemeriksaan lebih detil terhadap penumpang maupun kendaraan. Pada saat pemeriksaan kendaraan yang membawa pelaku dan korban, petugas menemukan dua orang bersembunyi di bawah tumpukan tas pada bagasi belakang mobil. Mendapati fakta itu, petugas kemudian memeriksa keduanya. Dua korban yang ditumpuk tas itu keadaannya sehat, mereka dikondisikan oleh IT untuk sembunyi di bagasi belakang sebelum memasuki PLBN. Atas perbuatan ini, pelaku dijerat UU Nomor 18 Tahun 2017 tentang Perlindungan Pekerja Migran Indonesia dengan ancaman hukuman 10 tahun penjara. ${ }^{24}$

Pada kasus percobaan penyelundupan ini, para korban tidak turut andil dalam penyelundupan. Namun mereka secara sadar dan sengaja diselundupkan dengan alat angkut. Para korban memang berniat untuk melewati batas wilayah suatu negara tanpa melalui tempat pemeriksaan imigrasi. Namun dalam

24 Ade Putra, "Imigrasi Entikon-Bongkar Modus Baru Penyelundupan Manusia Ke Malaysia," okezone. com, 2019. hal pelaksanaannya, mereka menyerahkan proses dan cara masuk tanpa melalui tempat pemeriksaan imigrasi pada penyelundup dan mereka hanya bersifat pasif. Namun dengan kepasifannya itu para korban telah dengan segaja memberi bantuan kepada penyelundup untuk melakukan tindak pidana. Di luar dari tindak pidana penyelundupan manusia, dengan kepasifannya para korban telah memenuhi unsur delik pada UU No.6 Tahun 2011 Tentang Keimigrasian pasal 113 yang berbunyi: "Setiap orang yang dengan sengaja masuk atau keluar Wilayah Indonesia yang tidak melalui pemeriksaan oleh Pejabat Imigrasi di Tempat Pemeriksaan Imigrasi sebagaimana dimaksud dalam Pasal 9 ayat (1) dipidana dengan pidana penjara paling lama 1 (satu) tahun dan/atau pidana denda paling banyak Rp100.000.000,00 (seratus juta rupiah)".

\section{Pemidanaan Kepada Korban yang Turut Serta dalam Terjadinya Penyelundupan Manusia}

Pada dasarnya pidana itu merupakan suatu penderitaan/nestapa yang diberikan oleh negara kepada seseorang, dan hanya merupakan alat (instrumen) belaka, karenanya tidak mungkin ia dapat mencapai tujuan. Untuk mencapai tujuan, pidana memerlukan dukungan konsep pemidanaan. Mengingat pemidanaan sinonim dengan perkataan penghukuman. Penghukuman itu berasal dari kata dasar hukum, sehingga dapat diartikan sebagai menetapkan hukum atau memutuskan tentang hukumnya (berechten). ${ }^{25}$

Pemerintah Indonesia telah berusaha memberantas penyelundupan manusia. Indonesia sudah meratifikasi konvensi United Nations Convention Against Transnational Organized Crime dan mengharmonisasikan ke dalam hukum nasional melalui Undang-Undang

25 M. Zen Abdullah, Pidana Penjara Eksistensi Dan Efektifitasnya Dalam Upaya Resosialisasi Narapida (Yogyakarta: Hasta Cipta Mandiri, 2009). 
No. 5 tahun 2009 tentang Pengesahan United Nations Convention Against Transnational Organized Crime (Konvensi Perserikatan Bangsa-Bangsa Menentang Tindak Pidana Transnasional yang Terorganisasi) dan protokol tambahan dari UNTOC yaitu Protokol Against The Smuggling of Migrant by Land, Sea, and Air, Supplementing the United Nations Convention Against Transnational Organized Crime dan mengharmonisasikan ke dalam hukum nasional melalui Undang-undang No. 15 Tahun 2009 tentang Pengesahan Protokol Against The Smuggling of Migrant by Land, Sea, and Air, Supplementing the United Nations Convention Against Transnational Organized Crime (Protokol Menentang Penyelundupan Migran Melalui Darat, Laut, dan Udara, Melengkapi Konvensi Perserikatan Bangsa-Bangsa Menentang Tindak Pidana Transnasional yang Terorganisir).

Selain melalui pembentukan hukum nasional, pemerintah Indonesia telah melakukan upaya lain seperti bekerjasama dengan negara lain, membentuk Satuan Tugas, melakukan kerjasama antar instansi dan memberikan hukuman yang berat kepada pelaku penyelundupan manusia. Semua ini dilakukan dalam upaya memberantas penyelundupan manusia.

Mengenai korban kejahatan, terdapat suatu studi yang mempelajari tentang korban penyebab timbulnya korban dan akibat penimbulan korban yang merupakan masalah manusia sebagai suatu kenyataan sosial yang disebut dengan Viktimologi. ${ }^{26}$ Melalui viktimologi dapat diketahui berbagai aspek yang berkaitan dengan korban seperti: faktor penyebab munculnya kejahatan, bagaimana seseorang dapat menjadi korban, upaya mengurangi terjadinya korban kejahatan, hak

26 Rena Yulia, Viktimologi Perlindungan Hukum Terhadap Korban Kejahatan (Yogyakarta: Graha Ilmu, 2010). dan kewajiban korban kejahatan. ${ }^{27}$

Tujuannya tidaklah untuk menyanjungnyanjung pihak korban, tetapi hanya untuk memberikan beberapa penjelasan mengenai kedudukan dan peran korban serta hubungannya dengan pihak pelaku serta pihak lain. Kejelasan ini adalah sangat penting dalam rangka mengusahakan kegiatan pencegahan terhadap berbagai macam viktimisasi, demi menegakkan keadilan dan meningkatkan kesejahteraan mereka yang terlihat langsung dalam eksistensi suatu viktimisasi. ${ }^{28}$

Melihat hubungan antara pelaku dan korban penyelundupan manusia, maka istilah yang tepat untuk menggambarkan orang-orang yang berniat untuk diselundupkan adalah objek kejahatan bukan korban kejahatan. Hal ini karena mereka tidak mengalami penderitaan, baik fisik, mental, maupun emosional, kerugian ekonomi, atau mengalami pengabaian, penguruangan, atau perampasan hak-hak dasarnya. Namun mereka hanya menjadi objek dari tindak pidana penyelundupan manusia. Karena tujuan utama dari pelaku penyelundupan bukanlah untuk merampas, memanfaatkan, atau memberikan penderitaan kepada mereka.

Berkaitan dengan tujuan pemidanaan, dikenal teori relatif yang menganggap dasar hukum dari pemidanaan bukanlah pembalasan, akan tetapi tujuan dari pidana itu sendiri. Jadi teori ini menyadarkan hukuman pada maksud dan tujuan pemidanaan itu, artinya teori ini menjadikan dasar penjatuhan hukuman pada maksud dan tujuan hukuman sehingga ditemukan manfaat dari suatu penghukuman. Jadi teori relatif bertujuan untuk mencegah agar ketertiban dalam masyarakat tidak terganggu. Teori relatif juga sering di sebut sebagai teori penangkalan, istilah penangkalan merupakan

\footnotetext{
27 Arief Mansyur, Dikdik M, and Elisatris Gultom, Urgensi Perlindungan Korban Kejahatan: Antara Norma Dan Realita (Jakarta: Raja Grafindo Persada, 2007).

28 Yulia, Viktimologi Perlindungan Hukum Terhadap Korban Kejahatan.
} 
terjemahan dari kata "deterrence". Teori penangkalan mempunyai suatu asumsi bahwa manusia selalu rasional dan selalu berpikir sebelum bertindak dalam rangka 'mengambi manfaat maksimal yang rasional' yang berarti bahwa prospek untung dan rugi ditimbang dengan keputusan-keputusan dan pilihanpilihan secara kalkulatif. ${ }^{29}$

\section{PENUTUP}

Dalam hal terjadinya kejahatan tindak pidana penyelundupan manusia posisi korban juga melakukan penyertaan pidana dan dapat dikenai hukuman atas perbuatan tersebut. Bentuk penyertaan yang korban lakukan berupa bersama-sama dengan pelaku mewujudkan delik penyelundupan manusia ataupun pembantuan pasif. Sehingga pertanggungjawabannya, para korbanyangturutsertadihargaisendiriyang berat ringannya sesuai dengan bentuk dan luasnya wujud perbuatan masing-masing orang dalam mewujudkan tindak pidana. Dalam terjadinya tindak pidana penyelundupan manusia, para korban menyetorkan sejumlah uang kepada pelaku. maka gambaran yang tepat untuk korban yang turut serta adalah objek penyelundupan manusia. Istilah korban kurang tepat karena mereka tidak mengalami penderitaan, baik fisik, mental, maupun emosional, kerugian ekonomi, atau mengalami pengabaian, penguruangan, atau perampasan hak-hak dasarnya oleh para pelaku penyelundupan manusia. Oleh karena itu, posisi korban kejahatan dan adanya niat yang disangkakan dapat menjadi dasar dari penentuan regulasi hukum bagi korban yang terlibat dalam tindak pidana. Hal ini perlu kewaspadaan dan sikap cermat penegak hukum dalam menganalisis berat dan ringannya hukuman yang akan disangkakan pada korban.

\footnotetext{
29 Salman Luthan, Kebijakan Kriminalisasi Di Bidang Keuangan (Yogyakarta: FHUII Press, 2014).
}

\section{DAFTAR PUSTAKA}

Abdullah, M. Zen. Pidana Penjara Eksistensi Dan Efektifitasnya Dalam Upaya Resosialisasi Narapida. Yogyakarta: Hasta Cipta Mandiri, 2009.

Evlyn Martha Julianty, Dahlan Ali, Mujibussalim. "Kebijakan Kriminal Dalam Penanggulangan Penyelundupan Manusia Di Indonesia." Jurnal Ilmu Hukum Pascasarjana Universitas Syiah Kuala 2, no. 2 (2014): 41.

I Wayan Pathriana. "Hukum Perjanjian Internasional." In 2, 261-63. Bandung, 2005.

Iman Achdiat. "Sindikat Penyelundupan Manusia Dibongkar Imigrasi Soetta." Air Magazine. Jakarta, 2017.

Junef, Muhar. "Kajian Praktik Penyelundupan Manusia Di Indonesia (Study of People Smuggling Practices in Indonesia)." Jurnal Pendidikan Hukum De Jure 20, no. 1 (2020): 85-102.

Kadarudin. "People Smuggling Dalam Perspektif Hukum Internasional Dan Penegakan Hukumnya Di Indonesia." Jurnal Perpustakaan XII, no. 2 (2013): 69-70.

Kartanegara, Satochid. "Kumpulan Kuliah Hukum Pidana." In 1, 419. Balai Lektur Mahasiswa, n.d.

Luthan, Salman. Kebijakan Kriminalisasi Di Bidang Keuangan. Yogyakarta: FHUII Press, 2014.

Mansyur, Arief, Dikdik M, and Elisatris Gultom. Urgensi Perlindungan Korban Kejahatan: Antara Norma Dan Realita. Jakarta: Raja Grafindo Persada, 2007.

Migration, International Organization for. Penyelidikan Dan Penyidikan Dalam Tindak Pidana Penyelundupan Manusia, 2012. 
Muhadar. Viktimisasi Kejahatan Pertanahan. Yogyakarta, 2006.

Mulyadi, Lilik. Kapita Selekta Hukum Pidana Kriminologi Dan Viktimologi. Denpasar, Bali: Djambatan, 2017.

Putra, Ade. "Imigrasi Entikon-Bongkar Modus Baru Penyelundupan Manusia Ke Malaysia." okezone.com, 2019.

Salam, Eka Annisa. "Penegakan Hukum Tindak Pidana Penyelundupan Manusia Dalam Hukum Positif Indonesia" 3, no. April 2020 (2020): 9-20.

Santoso, M. Imam. Hukum Pidana Internasional. Bandung: Pustaka Reka Cipta, 2013.

Santoso, M. Iman. Prespektif Imigrasi Dalam United Nation Convention Against Transnational Organized Crime. Edited by Perum Percetakan Negara RI. Jakarta, 2007.

Saragih, Yasmirah Mandasari, Ahmad Zaharuddin, Sani B Ahmad, and Roziya Abu. "Penegakan Hukum Terhadap Pelaku Penyelundupan Manusia Ke Indonesia" 4, no. 1 (2021): 161-74.

Sianturi, SR. Asas-Asas Hukum Pidana Di Indonesia Dan Penerapannya. Jakarta: Storia Grafika, 2002.

Soekanto, Soerjono. Faktor-Faktor Yang Mempengaruhi Penegakan Hukum. Jakarta: PT. Raja Grafindo Persada, 2008.
Soesilo, R. Kitab Undang-Undang Hukum Pidana (KUHP) Serta Penjelasannya Pasal Demi Pasal. Bogor, 1985.

Sohuturon, Martahan. "Bareskrim Ungkap Sindikat Penyelundupan Orang Ke Australia." cnn indonesia, 2019.

Subagyo, Agus, and Dadang Sobar Wirasuta. "Penyelundupan Manusia Dan Ancaman Keamanan Maritim Indonesia Desember 2013." Jurnal Pertahanan 3, no. 3 (2013): 155.

Subana. Dasar-Dasar Penelitian Ilmiah. Bandung: CV Pustka Setia, 2010.

Sugiarto, Umar Said. Pengantar Hukum Indonesia. Jakarta: Sinar Grafika, 2015.

Syamsu, Muhammad Ainul. Pergeseran Turutserta Melakukan Dalam Ajaran Penyertaan, Telaah Kritis Berdasarkan Teori Pemisahan Tindak Piana Dan Pertanggungjawaban Pidana. Prenadamedia Group, 2014.

United Nations, Protokol Against The Smuggling of Migrant by Land, Sea, and Air. Supplementing the United Nations Convention Against Transnational Organized Crime (n.d.).

UNTOC. United Nations, Convention Against Transnational Organized Crime (n.d.).

Yulia, Rena. Viktimologi Perlindungan Hukum Terhadap Korban Kejahatan. Yogyakarta: Graha Ilmu, 2010. 